\title{
NATURAL CALAMITIES AND ENVIRONMENTAL REFUGEES IN BANGLADESH
}

\author{
Muinul Islam
}

\section{Ecological Catastrophes In Bangladesh}

Bangladesh is one of the most disasterprone countries of the world. Whenever the country hits the headlines of the world press and the other media, some natural or man-made calamities occupy the centre of attention, playing havoc with human lives, crops, cattle raising, poultry, fishery, houses, roads, forests and many other types of property and economic infrastructure.

The loss of about half a million people during the 1970 cyclone and tidal surge stunned the world into disbelief about the killing potential of such a natural phenomenon. After the colossal losses of humanlife during the two major man-made disasters of the liberation war of 1971 and the famine of 1974, natural calamities have again emerged as the major killers in this region during the last decade, the most recent devastation being the cyclone and tidal surge of 29 April 1991.

Already recognized as the most severe cyclone of the century to hit the region, it has killed more than 140,000 people, which does not surpass the number of casualties during the 1970 cyclone, but this cyclone caused more widespread havoc in terms of crops, property and infrastructure than any other natural disaster in the country's history. Killer cyclones capture world attention because of the catastrophic toll they take on human life and resources, but they are only a few in a long series of natural calamities that frequently afflict Bangladesh, even several times a year.

Muinul Islam is Associate Professor in the Department of Economics, University of Chittagong, Bangladesh.

This article is an abridged version of a paper presented by the author at the Conference on "Worldwide Refugee Movements, Development Politics and Human Rights." (New York, November 8-9, 1991).
From the Bangladesh Bureau of Statistics publication, from which we compiled Table 1, we find that the decades of the sixties and the seventies of this century are the most turbulent in terms of cyclones with sixteen and fourteen killer cyclones recorded in these two decades respectively (BBS: 25-29).

Cyclones and tidal surges are, no doubt, the most devastating of the natural disasters to hit the entire coastal belt and offshore islands of Bangladesh, but other types of disasters also hit different areas of Bangladesh quite frequently. Tornados and "norwesters" are regular visitors in the two yearly storm seasons of April-May and October-November. So are floods and flash floods, which inundate the lowlands and delta regions in different parts of the country several times each year during the monsoon rains. In some areas, norwesters are accompanied by incessant rains, which cause flash floods.

In a country situated at one of the great river deltas of the world, the Ganges-Jamuna-Meghna delta, it is natural that floods are a regular phenomena in Bangladesh. The economic life of the people is organized with this in mind, and the people have adjusted their lives to an ecosystem where floods are expected, and sometimes welcome visitors. But the severity and the timing of floods quite often surprise people. Some of the recent floods affected more than two-thirds of the total area of Bangladesh, and the devastation caused to crops, houses, roads, embankments, cattle, poultry, fishery and all other types of economic infrastructure was enormous. Floods take a smaller toll in terms of human life, but the magnitude of loss they cause in term of resources, such as in the floods of 1974, 1987 and 1988, may reach catastrophic proportions.
Besides floods and cyclonic storm surges, ecological phenomena like river and sea erosion, ${ }^{2}$ droughts, ${ }^{3}$ waterlogging, increasing salinity, ${ }^{5}$ siltation and drying-up of river beds, ${ }^{6}$ change of river course, ${ }^{7}$ spread of desertification, the receding of the ground water table, etc., have become part and parcel of the life of the people of Bangladesh. These phenomena do not make sensational news headlines, but the sum total of the economic losses incurred by them in different areas may in some years reach catastrophic proportions as well. Therefore, it is not surprising that natural calamities are inevitably mentioned as a crucial factor behind the impoverishment of the vast multitudes of people in Bangladesh.

Though it may provide a readymade excuse for apologists, whereby the major share of the blame for the inexcusable poverty and deprivation of the masses can be laid on the vagaries of nature, it is, no doubt, true that almost all economic activities in such an ecosystem are virtual gambles with nature.

It is quite natural that the poorer segments of the population should be the first to lose out in the gamble of life. If we analyze the social differentiation and the marginalization process in the rural areas of Bangladesh, we find that the changes in production relations in peasant societies are significantly intertwined with ecological factors as well as with institutional, social and political realities in Bangladesh. Impoverishment of the peasant cultivators and sharecroppers, increasing landlessness, gradual marginalization of the small landowners and peasant families, increasingly skewed land ownership distribution, agricultural indebtedness and pauperization of the small peasantry whatever the issue considered - the 
analysis cannot but consider the deleterious effects of adverse changes in the natural phenomena mentioned earlier and the sudden devastations caused by them.

\section{Refugees in Bangladesh}

In this paper, we focus our attention on the refugees of Bangladesh, who are uprooted from their rural homes by an amalgam of economic, social, institutional and political factors, as well as by consecutive onslaughts of natural disasters like floods, cyclones, river erosions, etc. Conceptually, these refugees are variously termed as "economic migrants," "distress migrants" or "compelled migrants," but the compulsive push of circumstances becomes so much a matter of life and death for the refugees fleeing the ravages of natural disasters that normally they have no choice but to migrate. Therefore, the term refugee is more appropriate than the term migrant.

For example, a marginal farmer or sharecropper loses two consecutive crops, one by flood during the early rainy season, the other by storm surges driven from the sea by the storm wind that inundates the field with saline water in the next storm season of October/ November. Such consecutive blows will leave no option for such a farmer but to rush to the city for survival. The farmer may or may not sell the last parcel of cultivable or homestead land, but the decision to migrate is not a matter of choice; it is brought forth by the sheer need for survival.

When a 20- to 30-foot high tidal surge driven by a hurricane storm raging at more than 250 kilometers per hour demolishes everything in its way, including houses, trees, properties and crops, people, cattle, poultry and fisheries are washed away to their death. If the survivors of such a catastrophe find shelter in a relief camp, they cannot simply decide to go back to their ravaged homes, because such a singularly powerful strike of nature completely destroys the economic base of people in the affected areas, and therefore their potential for earning a livelihood for a long time thereafter. Under these conditions, the decision to become a squatter in an urban area is not a matter of choice. A family whose entire property, both homestead and cultivable land, is lost to river erosion, may be fortunate enough to move to a safer place in the same locality, but more often that family has no option but to move to an urban slum.

The term "distress migrant," or "economic migrant" cannot bring out the real plight of these groups of displaced people. Even the term "economic refugee" seems to evoke connotations that tend to minimize the utter desperation and

Table 1: Major Cyclonic Storms and Tidal Surges in Bangladesh

\begin{tabular}{|c|c|c|c|}
\hline Date & Region & Phenomena & Death toll \\
\hline $\begin{array}{l}1960 \\
\text { Oct. } 9-10\end{array}$ & $\begin{array}{l}\text { Eastern Meghna } \\
\text { Estuary }\end{array}$ & $\begin{array}{l}\text { Severe cyclonic storm, } \\
\text { wave } 10 \mathrm{ft}\end{array}$ & 3,000 \\
\hline $\begin{array}{l}\text { 1960, } \\
\text { Oct. } 30-31\end{array}$ & Chittagong & $\begin{array}{l}\text { Severe cyclonic storm, } \\
\text { surge height } 20 \mathrm{ft}\end{array}$ & 8,149 \\
\hline $\begin{array}{l}\text { 1961, } \\
\text { May } 9\end{array}$ & $\begin{array}{l}\text { West Megna } \\
\text { Estuary }\end{array}$ & $\begin{array}{l}\text { Severe cyclonic storm, } \\
\text { wave } 8-10 \mathrm{ft}\end{array}$ & 11,468 \\
\hline $\begin{array}{l}\text { 1963, } \\
\text { May 28-29 }\end{array}$ & $\begin{array}{l}\text { Chittagong, } \\
\text { Cox's Bazar }\end{array}$ & $\begin{array}{l}\text { Severe cyclonic storm, } \\
\text { wave } 8-12 \mathrm{ft}\end{array}$ & 11,520 \\
\hline $\begin{array}{l}\text { 1965, } \\
\text { May 11-12 }\end{array}$ & Barisal & $\begin{array}{l}\text { Hurricane, } \\
\text { wave } 12 \mathrm{ft}\end{array}$ & 19,270 \\
\hline $\begin{array}{l}\text { 1965, } \\
\text { Dec. } 15-16\end{array}$ & $\begin{array}{l}\text { Cox's Bazar } \\
\text { and Teknaf }\end{array}$ & $\begin{array}{l}\text { Severe cyclonic storm, } \\
\text { wave } 8-10 \mathrm{ft}\end{array}$ & 873 \\
\hline $\begin{array}{l}\text { 1966, } \\
\text { Oct. } 10\end{array}$ & Sandwip & $\begin{array}{l}\text { Severe cyclonic storm, } \\
\text { wave } 20-22 \mathrm{ft}\end{array}$ & 850 \\
\hline $\begin{array}{l}\text { 1970, } \\
\text { Nov. 12-13 }\end{array}$ & Meghna Estuary & $\begin{array}{l}\text { Hurricane, storm } \\
\text { surge } 10-33 \mathrm{ft}\end{array}$ & $\begin{array}{r}300,000- \\
500,000\end{array}$ \\
\hline $\begin{array}{l}\text { 1985, } \\
\text { May 24-25 }\end{array}$ & $\begin{array}{l}\text { Chittagong, } \\
\text { Noakhali Coast }\end{array}$ & $\begin{array}{l}\text { Severe cyclonic storm, } \\
\text { surge height } 14 \mathrm{ft}\end{array}$ & 11,069 \\
\hline $\begin{array}{l}\text { 1988, } \\
\text { Nov. } 29\end{array}$ & Khulna & $\begin{array}{l}\text { Severe cyclonic storm, } \\
\text { surge height } 14.5 \mathrm{ft}\end{array}$ & 5,708 \\
\hline $\begin{array}{l}\text { 1991, } \\
\text { April 29* }\end{array}$ & $\begin{array}{l}\text { Chittagong, } \\
\text { Cox's Bazar }\end{array}$ & $\begin{array}{l}\text { Hurricane, storm } \\
\text { surge } 20-30 \mathrm{ft}\end{array}$ & 140,000 \\
\hline
\end{tabular}

Source: Compiled from Table 1.16, Bangladesh Bureau of Statistics, 1990 Statistical Yearbook of Bangladesh (BBS. Dhaka, 1990: 25-29)

*The data of the 1991 hurricane are incorporated from official data published in various newspapers. 
helplessness of such people. The word "refugee," long associated with war, civil strife, turmoil, political repression, famine and epidemics, seems to have stereotyped the concept. Khasiani, writing about refugee research in Africa, complains about this conceptual inadequacy (Khasiani: 371). He writes,

In defining refugees some studies restrict themselves to the narrower United Nations definition while others apply the slightly broader Organization of African Unity definition. Manyother studiesare not clear concerning the type of definition adopted. This renders the area of refugee studies vague, confusing, and of limited comparability. [He further laments,] ... refugee populations which settle spontaneously are excluded from estimates of refugee populations since they usually fall outside organised assistance. (ibid.: 373)

This conceptual confusion is particularly pertinent for "ecological refugees" who lose the sympathetic public attention after the initial media attention subsides, and the official relief camps are closed down. Rehabilitation of such refugees is almost always abandoned halfway; official quarters and relief organisations do not normally follow up on the camp-leavers to oversee the rehabilitation of their economic life.

We are concerned, then, to describe the process whereby ecological phenomena tend to accelerate the process of marginalization and pauperization of the lower rungs of the people of Bangladesh, and have been creating a distinct group of "environmental refugees" in the continuum of "economic refugees" in Bangladesh.

\section{Ecological Phenomena and Refugees in Bangladesh}

Among the poorer victims of ecological disasters like cyclones, tidal surges and floods, the worst affected of the immediate survivors normally seek shelter in relief camps for immediate succour provided by the government, various aid agencies, voluntary organizations and the general public. As the severity of the crisis caused by such a disaster subsides, the long and arduous problem of rehabilitation arises. It is generally admitted that the loss incurred by the poorer families among the victims is proportionately greater compared to their capacity to sustain such losses. Repair of dwellings, replacement of lost assets, cattle, poultry, furniture and fixtures, etc., add up to a stupefying burden, however meagre the value and volume of those properties and assets a poor family had before the disaster in an absolute sense. Therefore, a great many of them decide to eke out an existence in the urban areas.

They arrive in throngs, crowd the footpaths, railway stations, river terminals, all sorts of public buildings where they can get entry, parks, vacant plots, narrow strips of land by the sides of railway tracks, etc. As beggars, coolies, vendors, domestic servants, rickshawpullers, pushcart drivers, they try to earn a living for themselves and their family members. They are the floating population of the cities and towns of the Third World. It is estimated that about 3,000 people sleep in the platforms of Dhaka railway station, and 1,500 in the Sadarghat river terminal every night. These types of publicplaces are the initial shelters for the newly arriving destitutes.

They proceed to the slums and squatter colonies spread all over the cities or towns and their suburbs. The larger a city is, the greater is the number of its slums. A survey in 1983 estimated that eighteen percent of the migrant population in Dhaka city live in slums accounting for more than eight percent of the squatter poor (Centre for Urban Studies; Majumdar, 1989: 3). It is further estimated that about one and a half million people of Dhaka live in slums and squatter colonies, which comes to about twenty-five percent of the total population, estimated at around six million in 1991 (Majumdar, 1992). A

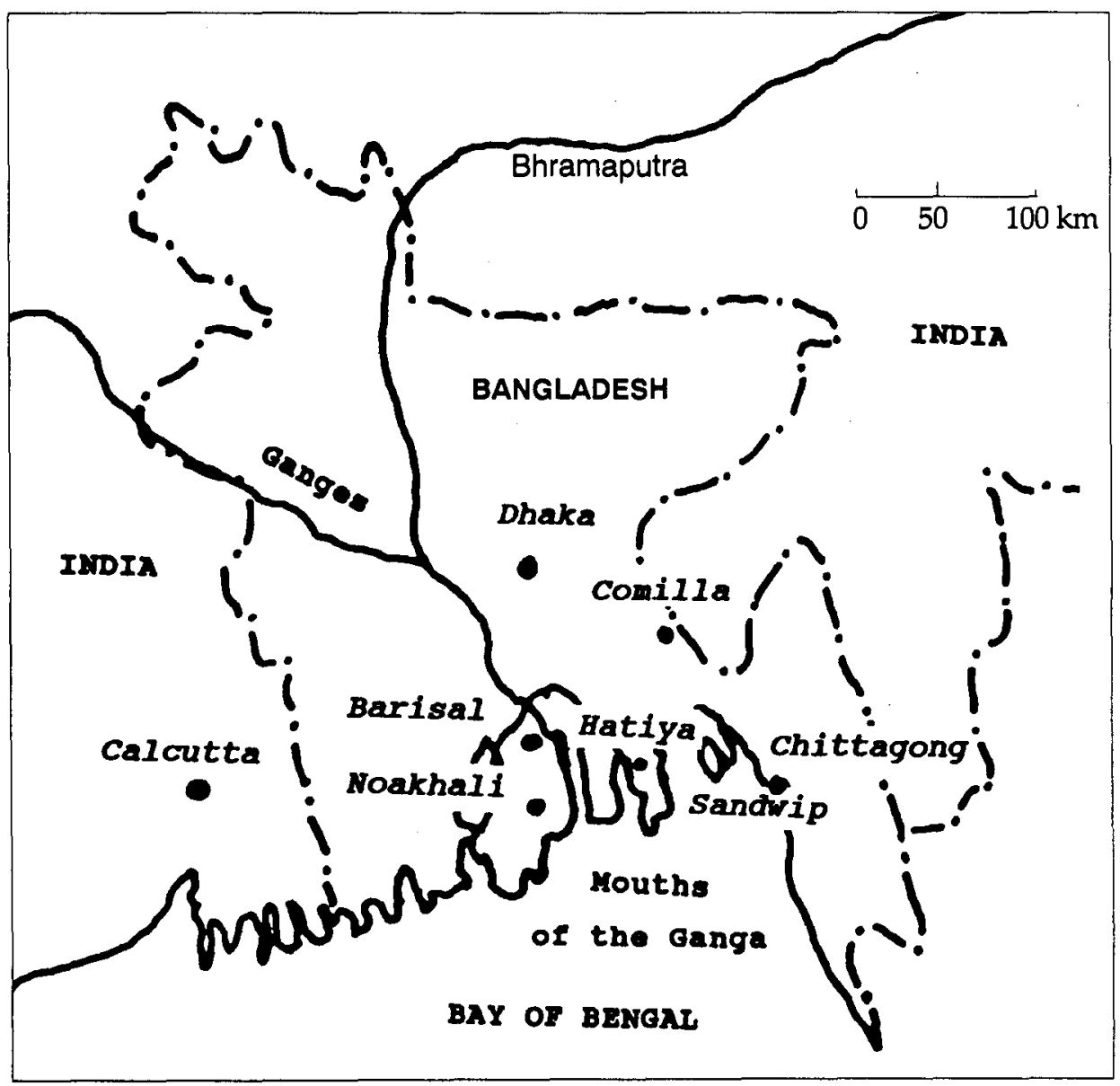

Fig: 1: Bangladesh 
significant proportion of these slumdwellers and almost all of the floating population can justifiably be counted as refugees rather than economic migrants or distress migrants, due to the absolutely minimal standard of living, health and sanitation they endure. The bare floor of the railway platforms is their bed; roadside drains are the latrines; they buy food from the footpath vendors; they carry their belongings around during daytime; street water taps and derelict ponds are their sources of water. Surely these arrangements are meagre even by the standards of refugee camps.

The Economic and Social Commission for Asia and the Pacific (ESCAP, UNO Agency) defines distress migration as that which is caused by periodic famines, droughts, floods and other natural calamities (ESCAP: 12). But the conditions of the environmental refugees of Bangladesh call for a redefinition of these people as refugees proper rather than migrants. Khasiani rightly comments:

This population is forced to migrate because of economic hardships which may be caused by environmental calamities or wars. This migration is in search of livelihood and their destination may be different areas within the same countries or across borders into neighbouring countries. These individuals are displaced and live in refugee-like conditions. (Khasiani: 371)

The fact that these refugees fall outside organised assistance should not restrict them from being categorised as refugees.

For the last two decades, these environmental refugees have also been moved to the relatively inaccessible and sparsely populated hilly areas of Chittagong Hill Tract, or CHT. A massive resettlement program encouraged by the government to counter the insurgency activities launched by the tribal nationalities of these areas has succeeded in attracting about half a million destitute and displaced people from the disasterprone coastal areas and off-shore islands into these hostile settlements. The wrong political designs of the rulers notwithstanding, this program is a cruel move, because these refugees are used as pawns and as the first line of defense against armed insurgents, who frequently attack, kill and plunder these hapless people in the settlements. In fact, these settlements could be considered as refugee colonies, the only difference being that these were established in the danger zones of Chittagong Hill Tract,

"A massive resettlement
program encouraged by the
government to counter the
insurgency activities
launched by the tribal
nationalities of these areas
has succeeded in attracting
about half a million destitute
and displaced people from
the disaster-prone coastal
areas and off-shore islands
into these hostile
settlements."

far away from the disaster-hit areas, to neutralize the numerical strength of different tribal nationalities in the disturbed areas.

The following excerpt from an article on this problem of insurgency will be instructive:

The abolition of its special status in 1964 opened up the CHT to large scale migration and to economic penetration by outsiders with a callous disregard for the traditions and interests of the indigenous population. From Dhaka the government has launched a systematic scheme to dilute the tribal population of the CHT by means of massive migration from the plains. In 1951 more than nine-tenths of the population of the CHT were tribal, but after the abolition of the excluded area status the demographic balance has altered dramatically: in 1974 the outsiders constituted twelve per cent of the total population; in 1980 it was about 35 per cent and, even though the current figures are not available, it is variously estimated that the tribal people by now have been outnumbered in their own home. Under the late President Zia-ur Rahman's directive a resettlement scheme was launched whereby 30,000 Bengali families were to settle in the CHT in 1979;25,000 families in 1980, and about 250,000 people in 1982. A settlement programme today continues unabated." (Rizvi: 42)

It is important to note that about 30,000 tribal refugees have fled to the refugee camps of India to escape from the counter-insurgency operations launched by the Bangladesh Armed Forces against the tribal insurgents. It is an ironic fate that ecological refugees are being lured to fill in the vacuum. Most of these refugees hail from the coastal areas of Chittagong, Noakhali, Patuakhali, Barisal, and the offshore islands of Sandwip, Hatiya and Bhola. They are displaced and driven out of their homes by cyclones, tidal surges, sea-erosion, change of course of rivers, etc. A noticeable percentage of the settlers hailing from Comilla, Noakhali, Faridpur and Barisal lost their homes and cultivablelands in river erosions and floods. The life risk posed by the insurgents called the Shanti Bahini was considered by these people to be an acceptable danger in the face of hunger and economic ruin caused by natural phenomena.

In support of our contention that environmental catastrophes like cyclones, tidal surges, serious floods, river erosions, sea erosions, etc., drive mainly the poor from their roots and turn them into economic refugees, we note some of the empirical findings of a recent survey conducted by G.S. Sahota (and others) on the victims of the 1988 flood of Bangladesh:

a) The loss of human life in the country was 5,000 , cattle 135,000 , and poultry birds 1.25 million. Over 2.2 million or one-seventh of all types of buildings and 19743 kilometres of roads and embankments were fully destroyed. The damage is a colossus... The losses of poultry, goats, cattle, dwellings, and household effects among these destitutes are assessed at 67 percent, 77 percent, 66 percent, 73 percent, and 56 percent, respectively, of the total value of the respective asset. The average respondent household lost assets worth about Bangladesh taka 
10,000 or approximately 70 percent of all assets (Sahota: 25);

b) Almost half of those interviewed (44.6 percent) had also sought refuge in a relief camp during the flood of 1987. Recurrence of similar floods most likely will force a certain segment of the population to become dependent on outside help, at least for a certain period, each time (26);

c) The findings of the relief camp survey suggest that the 1988 flood damage to this typically poor segment of the population has been colossal. They have lost more than half of their assets, paltry though they were to begin with (28);

d) The poor do suffer significantly more than the nonpoor in the sense that the losses of overall income of the poor are higher than those of the other strata of the society (29);

e) As many as 8.1 percent of sample households resorted to distress sales (29);

f) Natural disasters in disaster-prone Bangladesh hit the poor harder than the nonpoor.... both the intensity and the extent of damages are higher among the poor (39);

g) The extent of distress sales is approximately 2.5 times higher on the poor than the nonpoor (39);

h) The losses of overall income of the lower rungs of socioeconomic classes are at least ten per cent higher than those of the rest of society (39);

i) While the nonpoor may withstand a dissipation of a good part of their assets without bankrupting themselves, the poor are on thin ice. Once that ice breaks under their feet, it will take much longer for them to recover their balance again (39-40);

j) Both the intensity and the extent of unemployment caused by floods were consistently higher among spouses of lower socio-economic classes in comparison to spouses from upper socio-economic classes (40);

k) The poor are more vulnerable to the ravages of natural disasters than the average household in Bangladesh (41).

\section{Conclusion}

In a peripheral, neo-colonial state such as Bangladesh, the laws of motion of peripheral capitalism breed squatters and slum dwellers. The more aid that is accepted, the more aid-dependent the country becomes. While industry is virtually stagnant, agricultural production can hardly keep pace with the rapid population increase.

While the country can afford to pay less than half its import bill, the greater part of the government budget is spent on the military and the civil bureaucracy. A meagre 1.5 percent of the GDP goes to education, so not surprisingly the literacy rate has increased from 20 percent to only 25 percent in the last 40
In this paper, we focused on the ecological phenomena, and their effects in the acceleration of the marginalization process of the poorer classes of the society. From this viewpoint, our study may seem cursory. Admitting this limitation of our approach, however, we submit that ecological phenomena have a substantial impact on the changes in production relations in an ecosystem where nature may become a formidable adversary. But what is more important is that these ecological adversities can be effectively tackled through appropriate human efforts.

Cyclones and tidal surges are vagaries of nature, but the damages from them can be minimized with proper remedial measures like permanent

\section{"Cyclones and tidal surges are vagaries of nature, but the damages from them can be minimized with proper remedial measures like permanent embankments, planned coastal afforestation, cyclone shelters, concrete fortifications, modern warning systems, adequate rescue facilities, well-planned preparedness programs, effective relief programs, etc."}

years. Only 0.65 percent of the GDP is spent on health. The alliance of the militarybureaucracy and the comprador merchant capitalists continue to plunder the country under the semblance of popular democracy with active, and quite often overbearing guidance of the donor countries and aid organisations. The country is a smugglers' paradise with active connivance of the law enforcing agencies and policy makers. The meagre domestic savings are not invested for any productive purpose; institutional credit is siphoned off by merchants and diverted to the "black empire" of smuggling and black marketing. Capital flight is rampant; poverty alleviation only gets lip-service in this scenario; the system rests on exploitation of the poor, and increasing concentration and centralisation of ownership in rural areas result in rapid rural to urban migration and swelling urban slums. embankments, planned coastal afforestation, cyclone shelters, concrete fortifications, modern warning systems, adequate rescue facilities, well-planned preparedness programs, effective relief programs, etc.

Floods are controllable; riverdredging, river-training, embankments, sluice gates, dams, barrages, etc., are techniques within the command of existing knowledge. Without further elaboration, what we emphasize is that people and their ecology have to be harmonized with sincere efforts by society. Thepriority has to be determined by the society itself, whether it needs flood control programs more urgently, or it needs to expand and modernize its armed forces and its bureaucracy on a priority basis.

The society has to decide whether it will beg from the whole world for relief materials for the refugees, or whether it will ask for help and assistance from the other nations of the world for building 
up an effective cyclone-protection system. In a class-oriented society like Bangladesh, the ruling groups will never surrender their vested interests. But people's power must speak up in a participatory democracy to compel public representatives to determine the real people-oriented priorities of the society. We agree with Sahota when he says that:

The country herself being a disaster-prone delta land and its poorer strata even more, any program to mitigate natural disasters or their impacts is a pro-poor program. Additionally, any program that is focused on alleviating poverty is a step toward minimizing the damages from natural disasters because the poorer a group of people the more vulnerable it is to incur heavy damages from such disasters. (Sahota: 41)

\section{"The society has to decide whether it will beg from the whole world for relief materials for the refugees, or whether it will ask for help and assistance from the other nations of the world for building up an effective cyclone-protection system."}

Sahota has marvelled at the indomitable spirit, fortitude and resilience of the people of Bangladesh who have restarted human activities after the 1988 flood to such a degree that it now seems as if nothing happened.

We believe that the poor of Bangladesh can brave the torments of ecological devastation if they effectively combine their indomitable spirit, fortitude and resilience in a democratic struggle to break the shackles of the ruling cliques of Bangladesh and their foreign mentors who have been ruthlessly keeping them helpless victims of nature for time immemorial. The poor of Bangladesh have to decide themselves. [

\section{Notes}

1. "Norwesters" are summer storms that hit localized targets in different areas of the country from March to June. They do not kill many people but cause enormous damage to houses, crops (especially rice), fruit trees, rivercraft and other economic infrastructure.

2. Bangladesh has a network of more than 700 rivers, about 3,000 tributaries and canals. The zigzag courses and the alluvial nature of the soil of the delta regions combine to create serious problems of erosion of river banks during the summer and rainy seasons when the river currents are particularly strong. The offshore islands of the Bay of Bengal and in the Meghna Estuary also routinely experience erosion of the coastal belt during the windy and violent months.

3. The northwestern part of the country suffers from occasional droughts during the months of November-May. Crop failures result from such droughts. Sometimes floods followed by droughts in a year or vice-versa cause consecutive crop failures, which accentuate marginalization and pauperization of peasants.

4. The very low and low categories of land are waterlogged for most parts of the year. Even the medium-low category of land suffers from waterlogging after the rainy season, especially after the floods and tidal surges. The unplanned construction of roads and silting up of river beds have led to a deterioration in this regard. A new dimension is added by the alarming magnitude of waterlogging problems in the urban centres of the country, including Dhaka and Chittagong. Unplanned expansion of houses, roads, urban sprawl and the deterioration and closure of drains, ditches and canals increase the waterlogging problem.

5. The problem of salinity took a serious turn in the southern delta region of Bangladesh after the erection by India of the Farakha Dam in the upstream of the river Ganges near the Indo-Bangladesh border. The dam reduces the dry-season flow of the river system of southern Bangladesh, fed by water from the Ganges-Padma. The lower parts of those rivers which become lean or dried up in the winter months because of diversion of water by the Farakha, are affected daily by high tides carrying saline water upstream.

6. Silting has increased alarmingly in all of Bangladesh's rivers because of vastly increased amounts of silt carried by river water from upper-riparian countries, as well as from catchment areas within Bangladesh. Added to this now is the problem of the drying up of river beds during six or seven months of the year because of construction of dams, barrages and irrigation projects in many major rivers flowing from India.

7. This is a natural problem of a country comprising deltaic regions, especially if the rivers are shallow and zigzag, and the soil is mainly alluvial. Some districts routinely lose human habitations and crop lands due to this problem.

8. Surprising though it may seem, the northwestern districts of Bangladesh are increasingly experiencing symptoms of desertification. Drying up of rivers, large-scale deforestation, excessive pumping up of sub-soil water, the withdrawal of water by the Farakka and Teesta dams in India are some factors responsible. The Barindh tract of Rajshahiappears to be the major affected area.

\section{References}

Bangladesh Bureau of Statistics, 1990 Statistical Yearbook of Bangladesh (BBS, Dhaka, 1990).

Centre for Urban Studies, Slums in Dhaka City -A Socio-economic Survey for Feasibility of Slum Clearance and Urban Renewal Programme in Dhaka City (CUS, Dhaka University, Dhaka, 1983).

ESCAP, Report of the Expert Group Meeting on Migration and Human Settlements, ESCAP (United Nations, Bangkok, 1977).

Khasiani, S.A., "Refugee Research in Africa: Problems and Possibilities," International Migration XXVIII, 3 (1990): 369-377.

Majumdar, P.P. et al., Squatter Life in the Argargaon Area, Draft Report (Mimeo) (BIDS, Dhaka, 1989).

Majumdar, P.P., "Basti Jibaner Gatishilata O Sthabirata (in Bengali)," Bangladesh Unnayan Samikka, (BIDS, Dhaka, 1992): 71-92.

Rizvi, G., "Bangladesh: Insurgency in the Hills," The Round Table 305, (1988): 39-44.

Sahota, G.S. et al., The extent and the Distribution of the 1988 Flood Damages in Bangladesh, ESEPP Working Paper 10, (HIID/ ESEPP, Planning Commission, Govt. of Bangladesh, Dhaka, 1988). 